\title{
ARTIKELEN
}

\section{Burnout: de stand van zaken}

\author{
Toon Taris, Irene Houtman \& Wilmar Schaufeli
}

\begin{abstract}
Dit artikel geeft een overzicht van de stand van zaken in het onderzoek naar burnout. Burnout is een syndroom van extreme vermoeidheid (uitputting), afstand nemen van het werk (distantie) en weinig vertrouwen in het eigen kunnen (verminderde competentie), waarbij de oorzaken voor deze aspecten gelegen zijn in hetzij de werksfeer, hetzij de manier waarop werknemers omgaan met stresserende aspecten in hun werk. Als werkgerelateerd fenomeen onderscheidt burnout zich van vergelijkbare psychische problematiek als depressie en overspanning. Ook blijken burnout en bevlogenheid verschillende begrippen.

Burnout kan worden vastgesteld door werkenden naar hun persoonlijke en subjectieve beleving van hun gezondheid te vragen. Objectieve manieren om burnout vast te stellen - bijvoorbeeld via psychofysiologische maten - zijn tot nu toe niet bruikbaar gebleken. De nadruk op burnout als werkgerelateerd fenomeen wordt ook duidelijk uit de theoretische perspectieven op oorzaken van burnout. Enerzijds kunnen persoonlijkheidskenmerken als neuroticisme en (over-)commitment een rol spelen, maar anderzijds ligt er een sterke nadruk op factoren in de werksfeer. Burnout heeft gevolgen voor zowel de organisatie als individuele werknemers; burnout is gerelateerd aan een hoger ziekteverzuim, een grotere kans op arbeidsongeschiktheid, en een lagere werkprestatie. Zowel persoons- als organisatiegerichte interventies kunnen een gunstig effect hebben op burnout.
\end{abstract}

Burnout - de term is een uit het Engels afkomstige metafoor die verwijst naar een toestand van psychische uitputting. In het Nederlands wordt ook wel gesproken van 'opgebrand zijn'. In de huidige betekenis komt het woord 'burnout' in het midden van de jaren zeventig van de vorige eeuw voor het eerst voor in de Verenigde Staten, waar de psychiater Herbert Freudenberger de term gebruikt om het proces van emotionele uitputting en demotivatie van jonge vrijwilligers in de gezondheidszorg te beschrijven (Schaufeli et al., 2009). Ongeveer tegelijkertijd doet de sociaal psychologe Christina Maslach onderzoek naar de manier waarop mensen omgaan met sterke emoties in het werk. Een van de mensen met wie ze haar werk bespreekt - een advocaat - vertelt haar dat het afstand nemen van de cliënten en de gevoelens van onmacht en vermoeidheid in dit veld bekendstaan als 'burnout' (Maslach \& Schaufeli, 1993).

Sindsdien heeft het begrip burnout in zowel de populaire als de wetenschappelijke literatuur veel aandacht gekregen. Het aantal wetenschappelijke publicaties waarin burnout werd onderzocht, is de afgelopen dertig jaar bijvoorbeeld gestaag

* Toon Taris en Wilmar Schaufeli zijn werkzaam aan de Universiteit Utrecht, Afdeling Sociale en Organisatiepsychologie, t.taris@uu.nl. Irene Houtman is werkzaam bij TNO te Hoofddorp. 
toegenomen. Een klein literatuuronderzoek in de psychologische database PsycINFO laat bijvoorbeeld zien dat er in 198256 artikelen met het woord 'burnout' in de titel werden gepubliceerd; in 1992, 2002 en 2007 waren dat er respectievelijk 87, 96 en 197; in 2012 waren dat er 224. Vier decennia na de 'ontdekking' van burnout staat dit fenomeen dus nog steeds in de belangstelling van onderzoekers.

Doel van dit artikel is de lezer een overzicht te geven van de stand van zaken in het wetenschappelijk onderzoek naar burnout. We bespreken eerst de conceptualisatie van burnout. We gaan daarna achtereenvolgens in op theoretische perspectieven op het ontstaan van burnout; het onderscheid met vergelijkbare psychologische toestanden als depressie, chronische vermoeidheid en het posttraumatisch stresssyndroom (PTSS); de meting van burnout; de consequenties van burnout voor de gezondheid en het functioneren van werknemers; en interventies die beogen burnout terug te dringen. Omdat er inmiddels veel onderzoek naar burnout beschikbaar is, richten we ons in deze bespreking vooral op recente overzichtsstudies en meta-analyses van de literatuur.

\section{Burnout: wat het is}

Gezien de ontstaansgeschiedenis van het begrip burnout is het niet verwonderlijk dat het fenomeen aanvankelijk vooral werd onderzocht in beroepen waarin contact met anderen (met name cliënten, patiënten en leerlingen) centraal staat. De veel geciteerde definitie van Maslach en Jackson (1981) bij de introductie van de eerste versie van de Maslach Burnout Inventory (MBI, de meest gebruikte vragenlijst om burnout te meten) stelt bijvoorbeeld dat burnout een 'syndrome of emotional exhaustion, depersonalization, and reduced personal accomplishment' is dat 'can occur among individuals who do "people work" of some kind' (p. 99). Het ging in de visie van deze auteurs dus om een werkgerelateerd syndroom dat zich manifesteert in termen van emotionele uitputting (vermoeidheid die veroorzaakt is door het moeten werken met andere mensen), depersonalisatie (een cynische en onverschillige houding ten aanzien van de mensen met wie men werkt), en verminderde persoonlijke bekwaamheid (twijfel aan het eigen vermogen om goed met andere mensen te kunnen werken).

Er is echter geen reden om te veronderstellen dat burnout zich uitsluitend bij beoefenaars van dergelijke 'contactuele' beroepen kan voordoen. In 1996 publiceerden Schaufeli et al. daarom een niet-beroepsspecifieke versie van de Maslach Burnout Inventory (MBI-GS, voor 'general survey'), die algemeen toepasbaar is. Sindsdien is ook veel onderzoek naar burnout in andersoortige beroepen uitgevoerd. De drie dimensies van de oorspronkelijke MBI werden gehandhaafd, zij het dat de expliciete relatie met het werken met mensen verdween. De drie dimensies van de MBI-GS zijn respectievelijk uitputting (een gevoel van extreme vermoeidheid vanwege het werk), distantie (afstand hebben van het werk) en verminderde competentie (twijfel aan het eigen beroepsmatige functioneren). Sindsdien heeft onderzoek naar de structuur en validiteit van dit instrument laten zien dat de eerste twee dimensies (uitputting en distantie) gewoonlijk hoog samenhangen en 
ook op dezelfde manier gerelateerd zijn aan andere concepten, terwijl verminderde competentie juist relatief laag met de eerste twee dimensies samenhangt (en vaak ook op een andere manier aan andere concepten gerelateerd is). Dit heeft geleid tot de conclusie dat uitputting en distantie de kerncomponenten van burnout zijn (Schaufeli \& Taris, 2005).

\section{Burnout: theoretische kaders}

Burnout is de afgelopen decennia vanuit verschillende theoretische kaders bestudeerd. Deze kunnen globaal worden ingedeeld in omgevings-/werkgerichte en persoonsgerichte benaderingen.

\section{Werkkenmerken als antecedenten van burnout}

De belangrijkste groep benaderingen van waaruit burnout is bestudeerd, richt zich op de werkgebonden antecedenten van burnout. De veronderstelling daarbij is dat de aan- of afwezigheid van bepaalde werk- dan wel taakkenmerken (zoals een overmaat aan werkdruk of een tekort aan regelmogelijkheden en sociale steun) de kans bevordert dat burnout zal optreden.

Taakeisen, regelmogelijkheden en sociale steun. Veel onderzoek naar burnout richt zich op specifieke kenmerken van de taak/het werk als voorspellers van burnout. Het veruit bekendste model in deze traditie is het Job Demands-Control (JDC)model van Karasek (1979; Karasek \& Theorell, 1990), dat veronderstelt dat de combinatie van hoge taakeisen en weinig regelmogelijkheden zal leiden tot hoge niveaus van stress en ongezondheid. De overzichtsartikelen van Van der Doef en Maes (1999), De Lange et al. (2003) en Hausser et al. (2010) laten zien dat (vooral) hoge taakeisen en (in mindere mate) weinig regelmogelijkheden samenhangen met ongunstige scores op de dimensies van burnout. De effecten van taakeisen en regelmogelijkheden staan gewoonlijk los van elkaar (Taris, 2006a), zodat - in tegenstelling tot wat het JDC-model veronderstelt - het negatieve effect van hoge taakeisen op burnout niet automatisch verdwijnt of zwakker wordt als er sprake is van veel regelmogelijkheden. In een enkele studie is er echter wel een gezamenlijk effect van taakeisen en regelmogelijkheden aangetoond. Teuchmann et al. (1999) lieten bijvoorbeeld zien dat regelmogelijkheden een bufferend effect kunnen hebben tijdens een periode van hoge werkdruk in de organisatie.

Het JDC-model is later uitgebreid met sociale steun. Hoewel het ervaren van veel sociale steun samenhangt met lagere niveaus van burnout (De Lange et al., 2003; Hausser et al., 2010; zie ook Luchman \& Gonzàlez-Morales, 2013), lijkt ook een hoge mate van steun het negatieve effect van hoge taakeisen op burnout niet te kunnen compenseren.

Reciprociteit. Een sociaalpsychologisch georiënteerde theoretische stroming gaat ervan uit dat de relatie tussen een werknemer en diens werkgever opgevat kan worden als een uitwisselingsrelatie (Adams, 1965), waarbij de werknemer 'investeert' in het werk (bijvoorbeeld in termen van inspanning, kennis en betrokkenheid) en daaruit ook 'opbrengsten' terugkrijgt (bijvoorbeeld een salaris, werk- 
zekerheid, aanzien, sociale contacten). Voor de individuele werknemer kan dan worden bekeken of de verhouding tussen diens investeringen en opbrengsten in balans' is. Als de investeringen te hoog zijn ten opzichte van de opbrengsten, leidt dat tot vermoeidheid, frustratie en afstand nemen van het werk - met andere woorden, burnout (zie Schaufeli, 2006, voor een overzichtsstudie). Interessant is dat een teveel aan opbrengsten ten opzichte van de investeringen eveneens (geringe) negatieve gevolgen kan hebben voor het welzijn van werknemers (Van Dierendonck et al., 1996), wellicht omdat zulks leidt tot schuldgevoelens.

Eveneens voortbouwend op het idee van reciprociteit ontwikkelde Johannes Siegrist het Effort-Reward Imbalance (ERI)-model (2002), waarin vanuit het gezichtspunt van de individuele werknemer gefocust wordt op een beperkt aantal specifiek omschreven investeringen (fysieke inspanning, tijdsdruk, taakinterrupties) en opbrengsten (geld, waardering, zekerheid en ontwikkelingsmogelijkheden). Een overzichtsstudie van Van Vegchel et al. (2005) van zes empirische studies liet zien dat naarmate deze investeringen toe- en de opbrengsten afnamen, de scores op de drie dimensies van burnout minder gunstig werden. Dit ondersteunt het idee dat de verhouding tussen de investeringen van een werknemer in diens werk en de opbrengsten daarvan gerelateerd is aan burnout, waarbij met name de situatie waarin deze investeringen de opbrengsten overtreffen een hoger risico op burnout met zich meebrengt.

Taakeisen en hulpbronnen. Waar Karaseks (1979) JDC-model betrekking had op twee specifieke taakkenmerken (taakeisen en regelmogelijkheden), maakt het recentere Job Demands-Resources (JDR)-model (Demerouti et al., 2001) onderscheid tussen twee brede categorieën van taakkenmerken: taakeisen (eenvoudig gezegd, de aspecten van de taak die inspanning vereisen en die gerelateerd zijn aan de centrale doelen van het werk; denk aan kwantitatieve, emotionele en kwalitatieve taakeisen) en hulpbronnen (aspecten van het werk die helpen deze doelen te bereiken, dan wel de daarvoor benodigde inspanning verlichten; bijvoorbeeld regelmogelijkheden en sociale steun, maar ook een goed salaris, goede werkroosters, enzovoort). Een in de context van dit artikel interessant verschil met Karaseks (1979) JDC-model en Siegrists (2002) ERI-model is dat het JDRmodel in termen van de mogelijke antecedenten van burnout geen specifieke taakkenmerken noemt, maar het alleen heeft over 'taakeisen' en 'hulpbronnen': de concrete invulling van deze categorieën varieert van baan tot baan (en van studie tot studie). Overigens kunnen ook het JDC-model en het ERI-model heel goed worden aangevuld met andere taakkenmerken, maar in de praktijk maken onderzoekers nauwelijks gebruik van deze mogelijkheid. Recente overzichtsstudies van Crawford et al. (2010), Luchman en Gonzàlez-Morales (2013) en Schaufeli en Taris (2013) laten zien dat (consistent met het onderzoek naar het JDC-model) het hebben van hoge taakeisen en weinig hulpbronnen gerelateerd is aan hoge niveaus van burnout. Ook hier is onderzoek gedaan naar de mogelijke gecombineerde effecten van taakeisen en hulpbronnen, en ook hier geldt (evenals voor het JDC-model) dat deze gecombineerde effecten gewoonlijk niet worden gevonden (Schaufeli \& Taris, 2013).

Eén mogelijke verklaring voor het ontbreken van dergelijke gecombineerde effecten is dat dergelijke effecten vooral dán zullen optreden als taakeisen, hulpbron- 
nen en uitkomsten betrekking hebben op hetzelfde conceptuele domein (De Jonge \& Dormann, 2006). Emotionele belasting zal bijvoorbeeld in principe leiden tot hogere niveaus van emotionele uitputting, maar de aanwezigheid van voldoende sociale ondersteuning kan ervoor zorgen dat de relatie tussen taakeis en uitkomst zwakker wordt of zelfs verdwijnt. Is er daarentegen geen sprake van een conceptuele match tussen taakeis, hulpbron en uitkomst, dan is er evenmin reden om te verwachten dat deze taakeis en hulpbron een gecombineerd effect op de uitkomst zullen hebben. Bijvoorbeeld, waarom zou de aanwezigheid van een bedlift ervoor zorgen dat de hoge emotionele belasting van een verpleegkundige een minder sterk effect heeft op haar/zijn niveau van emotionele uitputting? De Jonge en zijn collega's hebben deze redenering inmiddels in een aantal studies onderzocht en vonden ondersteuning voor het idee dat naarmate de conceptuele overeenkomst tussen taakeis, hulpbron en uitkomst sterker wordt, het aantal interacties toeneemt (zie De Jonge et al., in druk, voor een overzicht).

Inspanning-herstel. Een laatste belangrijk theoretisch perspectief van waaruit burnout is bestudeerd, is dat van Meijman en Mulder (1998): de Effort-Recovery (E-R)-theorie. Deze theorie veronderstelt dat het moeten leveren van inspanning gepaard gaat met vermoeidheidsverschijnselen, zowel mentaal als fysiek. Men kan van deze vermoeidheid herstellen door voldoende rust te nemen. Doet men dat niet, dan zullen de vermoeidheidseffecten zich opstapelen en op den duur resulteren in (chronische) gezondheidsklachten, zoals burnout. In vanuit dit perspectief uitgevoerd onderzoek wordt gekeken naar de hoeveelheid inspanning (werkdruk, taakeisen, werkuren, werkroosters) die werkenden moeten leveren, in relatie tot de herstelmogelijkheden tijdens (pauzes) en na (overwerk, werk-thuisinterferentie) het werk. Hoewel specifiek op burnout gerichte overzichtsstudies afwezig zijn, biedt het beschikbare onderzoek (bijvoorbeeld Geurts et al., in druk; Hall et al., 2009; Taris et al., 2006) ondersteuning voor het idee dat de balans tussen inspanning en herstel belangrijk is voor het welzijn van werkenden. Misschien nog belangrijker, het E-R-model wordt wel gebruikt als onderbouwing van het idee dat hoge taakeisen het welzijn van werknemers beïnvloeden (bijvoorbeeld in het JDR-model; Schaufeli \& Taris, 2013).

\section{Persoonlijkheidskenmerken als antecedenten van burnout}

Burnout hoeft niet uitsluitend te wijten te zijn aan ongunstige kenmerken van de werkomgeving. Een tweede benadering bij het bestuderen van burnout richt zich daarom op de rol van persoonlijkheidskenmerken. Daarbij wordt verondersteld dat de aanwezigheid van specifieke persoonlijkheidstrekken de kans vergroot dat werknemers opgebrand zullen raken. Vanuit dit perspectief is een veelheid aan empirische studies uitgevoerd in allerlei specifieke beroepen (bijvoorbeeld leraren, politieagenten, priesters en verpleegkundigen) en zijn allerlei persoonlijkheidskenmerken onderzocht. Twee recente overzichtsstudies op dit terrein zijn die van Alarcon et al. (2009) en van Swider en Zimmermann (2010). Op basis van een meta-analyse van 115 studies laten Swider en Zimmerman zien dat de correlaties tussen de vijf dimensies van het Big-5-persoonlijkheidsmodel (openheid, consciëntieusheid, extraversie, neuroticisme en vriendelijkheid) en de drie componenten van burnout variëren van -,09 tot ,52 (mediaan ,28), waarbij de relaties 
met neuroticisme veruit het sterkst en die met openheid duidelijk het zwakst zijn. Hoge scores op neuroticisme en lage scores op de andere dimensies gaan samen met hoge scores op de dimensies van burnout. Alarcon et al. (2009) laten in aanvulling hierop zien dat ook positieve en negatieve affectiviteit en 'hardiness' (vrij vertaald als 'weerbaarheid', een combinatie van betrokkenheid, controle en uitdaging) belangrijke predictoren van burnout zijn: hoge scores op negatieve affectiviteit en lage scores op hardiness en positieve affectiviteit hangen samen met hogere scores op burnout.

De psychologische processen die aan de basis liggen van deze relaties verschillen per persoonlijkheidsdimensie. Zo zouden personen die hoog scoren op neuroticisme geneigd zijn de negatieve aspecten van een (werk)situatie te benadrukken en sowieso al een sterke tendens in de richting van negatieve gevoelens (waaronder burnout) te vertonen. Extraverte personen zouden juist positieve aspecten benadrukken; vriendelijke personen zouden meer begrip tonen voor de positieve én de negatieve aspecten van de werkomgeving; consciëntieuze personen zouden geneigd zijn zichzelf en hun werkprestaties positiever te beoordelen dan anderen; en open personen zouden problemen op het werk vooral zien als kansen voor verdere persoonlijke ontwikkeling in plaats van bronnen van frustratie (Swider \& Zimmermann, 2010).

Voortbouwend op de in de vorige paragraaf besproken modellen voor de relatie tussen werkkenmerken en burnout: het ERI-model van Siegrist (2002) stelt dat een zeer hoge commitment ('over-commitment') de negatieve gezondheidseffecten van een ongunstige balans tussen de door een werknemer in het werk geïnvesteerde effort en de rewards daarvan zal versterken. Dat over-commitment een positieve relatie heeft met burnout wordt in diverse studies bevestigd (bijvoorbeeld Lau, 2008; Van Vegchel et al., 2005).

Samenvattend, hoewel niet altijd duidelijk is welke psychologische processen verantwoordelijk zijn voor de samenhang tussen persoonlijkheidskenmerken en burnout, kan op basis van het bovenstaande wel worden geconcludeerd dat een aantal specifieke persoonlijkheidsaspecten inderdaad relatief sterke voorspellers van burnout zijn.

Theoretische kaders: samenvatting. Op basis van het onderzoek dat in de hiervoor besproken theoretische tradities is uitgevoerd, kan worden geconcludeerd dat de werksituatie een grote hoeveelheid risicofactoren voor burnout bevat. Enerzijds gaat het daarbij om de eisen die het werk stelt en de inspanning die werkenden vervolgens moeten leveren om aan die eisen tegemoet te komen (gemeten in termen van 'investeringen', 'taakeisen' of 'inspanning', afhankelijk van het gekozen theoretische raamwerk). Anderzijds zijn relevante clusters van risicofactoren 'gebrek aan regelmogelijkheden' of - breder - 'hulpbronnen', 'gebrek aan herstelmogelijkheden' en 'gebrek aan opbrengsten'. Hoewel de inspanningsgerelateerde factoren relatief eenduidig gedefinieerd kunnen worden, zijn de risicofactoren die in de drie andere categorieën kunnen worden geplaatst schier oneindig. Duidelijk is daarmee dat de werksituatie een grote verscheidenheid aan potentiële risicofactoren voor burnout bevat. Daarbij komt nog dat ook aspecten van de persoonlijkheid van de werknemer het risico op burnout kunnen vergroten of verkleinen. 
Met name neurotische en overbetrokken werknemers zullen een relatief grote kans op een burnout hebben. Cynici zouden op basis van deze veelheid aan risicofactoren kunnen concluderen dat er eigenlijk niet zoveel over de specifieke oorzaken van burnout gezegd kan worden; immers, alles is in potentie een risicofactor. Die stellingname is echter te extreem, in de zin dat de belangrijkste werkgerelateerde risicofactoren voor burnout (vooral overbelasting vanwege te hoge taakeisen en gebrek aan herstel; daarnaast ook gebrek aan relevante hulpbronnen dan wel adequate compensatie) inmiddels duidelijk zijn.

\section{Burnout versus andere psychische aandoeningen en bevlogenheid}

Hierboven hebben we aangegeven wat burnout is (een syndroom van emotionele uitputting, afstand hebben van het werk, en twijfelen aan de eigen competentie) en waar het mee samenhangt (persoonlijkheid en werksituatie). Hier gaan we in op de vraag hoe burnout zich verhoudt tot andere, min of meer vergelijkbare concepten als overspannenheid, depressie, posttraumatische stress, 'compassion fatigue' en chronische vermoeidheid, alsook tot 'bevlogenheid', dat wel als het 'tegengestelde' van burnout wordt gezien.

Eén belangrijk onderscheid tussen burnout en andere psychische aandoeningen is dat de oorzaak voor burnout geacht wordt te liggen in de werksfeer. De theoretische perspectieven die hierboven zijn besproken hebben gemeenschappelijk dat de risicofactoren voor burnout primair worden gezocht in de werksfeer. Dat geldt zelfs voor de persoonsgerichte benadering: hier wordt ervan uitgegaan dat persoonlijkheidstrekken bepalen hoe werknemers omgaan met werkgerelateerde risicofactoren (dit gezichtspunt impliceert dat niet-werkenden per definitie niet opgebrand kunnen zijn; vergelijk Schaufeli \& Taris, 2005). Fenomenen als overspannenheid, depressie, chronische vermoeidheid en posttraumatische stress kunnen wat betreft hun uitingsvorm overlappen met burnout, maar de wortels voor deze psychosociale problematiek zullen vaak liggen in andere dan het werkdomein en daarmee is dan vaak ook een andere aanpak geboden die zich vooral richt op factoren buiten de werksituatie.

Daarnaast heeft burnout zowel betrekking op uitputting (gebrek aan energie, niet meer kunnen) als op terugtrekken van het werk (gebrek aan motivatie, niet meer willen) en niet meer effectief kunnen zijn (persoonlijke onbekwaamheid; Schaufeli \& Taris, 2005). De combinatie van affectieve en motivationele aspecten is eveneens een belangrijk onderscheid met concepten als depressie en chronische vermoeidheid, en in die zin is burnout niet adequaat vast te stellen met - bijvoorbeeld - instrumenten die alleen het vermoeidheidsaspect van burnout in kaart brengen. Met behulp van diagnostische criteria kan burnout overigens onderscheiden worden van depressie en chronische vermoeidheid (Van der Heiden \& Hoogduin, 2002). Voorts blijkt dat burnout tot depressie kan leiden in plaats van andersom (Hakanen \& Schaufeli, 2012). Het is hier ook belangrijk om te onderkennen dat burnout niet alleen betrekking kan hebben op een toestand van uitputting (die niet fundamenteel verschilt van symptomen van depressie, surmenage of overspannenheid), maar ook op het proces van opbranden dat jarenlang 
kan duren. Het specifieke van het begrip burnout zou dan eerder liggen in het proces van psychische erosie dan in de eindtoestand van uitputting (Schmidt, 2001).

Het begrip 'compassion fatigue' refereert aan de stress die het gevolg is van de confrontatie met het lijden van anderen, en wordt wel gezien als een vorm van posttraumatische stress (Craig \& Sprang, 2010). Het fenomeen is dus strikt gekoppeld aan de omgang met anderen, en lijkt in dat opzicht op de oorspronkelijke conceptualisatie van burnout als een fenomeen dat primair optreedt in contactuele beroepen. De oorzaak voor compassion fatigue ligt echter specifiek in de confrontatie met andermans lijden, en het concept is daarmee veel minder breed dan burnout. Hoewel het aannemelijk is dat beide concepten empirisch vaak sterk zullen samenhangen, is het lastig hierover een uitspraak te doen. Uit ten behoeve van dit artikel uitgevoerd literatuuronderzoek bleek dat beide concepten weliswaar met enige regelmaat in dezelfde studie werden meegenomen, maar we hebben geen onderzoek kunnen vinden waarin de samenhang tussen deze concepten expliciet werd gerapporteerd.

Ten slotte, bevlogenheid refereert aan een positieve, affectief-cognitieve toestand van vitaliteit (een grote mate energie en doorzettingsvermogen), toewijding (een sterke betrokkenheid bij het werk) en absorptie (het op een plezierige wijze opgaan in het werk) (Schaufeli \& Bakker, 2004). De eerste twee dimensies (vitaliteit en toewijding) zijn directe tegenhangers van respectievelijk de dimensies uitputting en cynisme van burnout. Tussen burnout en bevlogenheid wordt altijd een negatieve relatie gevonden, wat in overeenstemming is met de opvatting dat bevlogenheid het tegendeel van burnout is. Overigens varieert de mate van samenhang sterk: beide begrippen overlappen empirisch tussen de 2-42\% (Halbesleben, 2010). Dit grote verschil wordt veroorzaakt doordat 'gebrek aan competentie' (de derde dimensie van burnout) veel sterker dan 'uitputting' of 'cynisme' samenhangt met bevlogenheid. Dit komt omdat 'gebrek aan competentie' wordt gemeten met positief geformuleerde vragen naar de eigen bekwaamheid (Halbesleben, 2010). Verder blijkt uit tal van psychometrische studies op basis van factoranalyse dat burnout en bevlogenheid twee verschillende begrippen zijn die ieder op een aparte factor laden (Schaufeli, 2012).

Geconcludeerd kan worden dat burnout inhoudelijk verwant is aan een reeks van concepten, maar daarvan verschilt omdat de oorzaken van het fenomeen strikt gebonden zijn aan de werksfeer. Het vaststellen van een burnout impliceert dus dat de oorzaken hiervoor in de werksfeer liggen, dan wel in persoonskenmerken die ervoor zorgen dat werkenden niet adequaat kunnen omgaan met de belastende aspecten van hun werk.

\section{Hoe kan burnout worden vastgesteld?}

In de wetenschappelijke literatuur is een keur aan vragenlijsten beschikbaar waarmee burnout kan worden gemeten. De bekendste en veruit meest gebruikte daarvan is de Maslach Burnout Inventory (MBI) (Maslach \& Jackson, 1981; Schaufeli et al., 1996), die burnout opvat als een combinatie van emotionele uitputting, het 
hebben van een afstandelijke houding ten aanzien van het werk, en verminderde persoonlijke bekwaamheid. De vragenlijst is uitgebreid gevalideerd en op zijn psychometrische merites onderzocht (zie Maslach et al., 2008, voor een overzicht) en kent drie versies die respectievelijk bestemd zijn voor mensen met contactuele beroepen, voor leerkrachten en voor de algemene populatie. Een belangrijk voordeel van deze lijsten (in Nederland bekend als de Utrechtse Burnout Schaal (UBOS); Schaufeli \& Van Dierendock, 2000) is dat ze ook voor het Nederlandse en Vlaamse taalgebied uitgebreid genormeerd en gevalideerd zijn. Er kan dus eenvoudig worden vastgesteld of een bepaalde persoon ten opzichte van een specifieke normgroep een problematische score op (de drie dimensies van) burnout behaalt (Schaufeli \& Van Dierendonck, 2000). De gebruikte afkappunten (die aangeven of iemand een al dan niet problematische score behaalt) zijn klinisch gevalideerd door de UBOS te laten invullen door personen die bij een psycholoog of psychiater onder behandeling waren vanwege 'werkgerelateerde neurasthenie'. Dat wil zeggen dat deze personen persistente lichamelijke en/of geestelijke vermoeidheid rapporteren in combinatie met een aantal psychosomatische klachten (zoals spanningshoofdpijn en maagklachten), zonder dat sprake is van een angst- of depressieve stoornis. De gemiddelde scores van deze personen op de UBOS zijn gebruikt om de afkappunten van de UBOS vast te stellen.

Een tweede instrument waarmee burnout in het Nederlandse taalgebied kan worden gemeten is de Oldenburg Burnout Inventory (OLBI) (Demerouti \& Bakker, 2007), die twee van de drie dimensies van burnout (uitputting en depersonalisatie/afstand van het werk) meet. Ten slotte, een sterk op de uitputtingsschaal van de MBI gelijkend instrument wordt door TNO en het CBS (Nationale Enquête Arbeidsomstandigheden; Koppes et al., 2013) gebruikt om burnoutklachten in kaart te brengen. Beide laatste instrumenten worden vooral gebruikt in wetenschappelijk onderzoek, bijvoorbeeld om verschillen in burnoutklachten tussen te vergelijken groepen werkenden in kaart te brengen. De MBI is daarnaast ook goed inzetbaar in de klinische praktijk.

Buiten het Nederlandse taalgebied zijn nog andere instrumenten ontwikkeld om burnout te meten. De interessantste daarvan is de door Tage Kristensen en zijn Deense collega's ontwikkelde Copenhagen Burnout Inventory (COBI) (Kristensen et al., 2005). Wellicht het belangrijkste verschil met de 'traditionele' benadering van burnout (waarin dit fenomeen wordt opgevat als een werkgerelateerde vorm van psychosociale problematiek) is dat de COBI burnout los van een specifieke context meet. De items van het instrument van Kristensen et al. hebben betrekking op vermoeidheid, maar nemen de bron daarvan niet mee. Deze conceptualisatie betekent de facto dat het onderscheid tussen burnout en vergelijkbare, meer generieke concepten als depressie en chronische vermoeidheid vervalt. Hierboven zagen we immers al dat het onderscheid tussen burnout en veel andere, vergelijkbare concepten te vinden was in het feit dat de oorzaken van burnout strikt in de werksfeer gevonden moeten worden (Schaufeli \& Taris, 2005).

Bovenstaande manieren om burnout vast te stellen gaan primair uit van de subjectieve beleving van de ondervraagden: zij geven zelf aan hoe uitgeput zij zich voelen, hoe groot de afstand is die zij ervaren tot hun werk, en in hoeverre zij twijfelen aan hun eigen capaciteiten. Een dergelijke manier van meten kan leiden tot 
allerlei vertekeningen. In het verleden is daarom ook geprobeerd om objectieve biomarkers van burnout op te sporen: denk aan hormoonspiegels, bloeddruk en dergelijke. Op basis van hun meta-analyse concluderen Danhof-Pont et al. (2011) echter dat er op dit moment geen potentiële biomarkers voor burnout zijn: er is dus geen duidelijk fysiologisch fenomeen op basis waarvan kan worden vastgesteld of iemand al dan niet opgebrand is.

Concluderend, burnout kan worden vastgesteld door respondenten te vragen naar hun subjectieve beleving van hun gemoedstoestand. Het gebruik van een gevalideerde en genormeerde vragenlijst (met name de MBI) ligt dan voor de hand. Dit betekent overigens niet dat burnout in de praktijk altijd met behulp van deze vragenlijst wordt vastgesteld. Zoals hierboven al eerder werd beschreven, is het onderscheid tussen burnout en aandoeningen zoals overspannenheid en depressie primair gelegen in de oorzaak van de klachten. Dat betekent dat een huisarts een burnout kan diagnosticeren met behulp van een depressievragenlijst zoals de vierdimensionele klachtenlijst (Terluin, 1998) als duidelijk is dat de oorzaak voor deze klachten gelegen is in de werksituatie. Voorts wordt er in de praktijk (in Nederland) ook een diagnostisch interview gebruikt waarbij burnout wordt opgevat als een werkgerelateerde vorm van neurasthenie, zoals vastgelegd in de International Classification of Diseases (ICD-10) (Van der Heiden \& Hoogduin, 2002). De validiteit van een vragenlijst die burnout vanuit dit perspectief probeert vast te stellen is echter vooralsnog onduidelijk (Verbraak et al., 2008).

\section{Gevolgen van burnout}

Ten slotte bespreken we de veronderstelde gevolgen van burnout, zowel voor de werknemer als voor de organisatie waarvoor deze werkzaam is. De meest voor de hand liggende gevolgen van burnout hebben betrekking op de gezondheid, het ziekteverzuim en de inzetbaarheid van de betreffende werknemer. In een uitgebreide overzichtsstudie laten Shirom en Melamed (2005) zien dat hoge niveaus van burnout samenhangen met een hogere kans op cardiovasculaire problemen, diabetes type II, en gewrichts- en spierproblemen. In lijn met deze bevindingen blijken werknemers die hoge burnoutscores rapporteren vaker (Ahola et al., 2008; Hallsten et al., 2011) en langduriger (Ahola et al., 2008; Schaufeli et al., 2009) ziek te zijn dan anderen, terwijl zij op langere termijn een hogere kans hebben om arbeidsongeschikt te raken (Ahola et al., 2009).

Maar ook als burnout niet direct consequenties heeft voor de gezondheid en het verzuim van werkenden, laat onderzoek negatieve gevolgen voor het functioneren van de werknemer zien. Werknemers met relatief hoge scores op burnout (met name de uitputtingscomponent) beoordelen hun eigen prestatie bijvoorbeeld gemiddeld lager dan anderen doen (Bakker et al., 2004; Bakker \& Heuven, 2006). Studies waarin objectieve prestatiematen werden betrokken, laten een vergelijkbaar beeld zien. De overzichtsstudie van Taris (2006b) liet zien dat de correlatie tussen de uitputtingscomponent van burnout en prestatie varieerde van ,19 tot ,55, afhankelijk van het type prestatie dat werd beoordeeld. 
Samenvattend, burnout heeft serieuze consequenties voor het functioneren en de gezondheid van werknemers. Werknemers met hoge scores op burnout presteren duidelijk minder goed dan hun collega's met lagere scores op burnout, zij melden zich vaker en langduriger ziek, en lopen een groter risico om op termijn arbeidsongeschikt te raken dan anderen.

\section{Burnout-interventies}

Het bovenstaande laat zien dat burnout zowel voor organisaties als voor individuele werknemers een probleem is. Uit onze bespreking van de theoretische perspectieven op het ontstaan van burnout bleek dat de oorzaken daarvoor in de werksfeer gezocht moeten worden, dan wel in de manier waarop werknemers omgaan met werkgerelateerde risicofactoren voor burnout. In die zin weten we inmiddels vrij goed hoe we ervoor kunnen zorgen dat werknemers minder gunstige scores op burnout rapporteren, of zelfs zich ziek melden vanwege burnout. Maar welke interventies kunnen het ontstaan van burnout voorkómen dan wel ervoor zorgen dat werknemers mínder burnout rapporteren?

In een overzichtsstudie waarin 25 tussen 1995 en 2007 beschreven burnoutinterventieprogramma's waren betrokken, maakten Awa et al. (2010) onderscheid tussen persoonsgerichte interventies ( 17 van de 25 interventies), organisatiegerichte interventies ( 2 van de 25 interventies) en interventies waarin het persoonsgerichte en organisatiegerichte perspectief waren gecombineerd (6 interventies). Persoonsgerichte interventies hadden bijvoorbeeld vaak betrekking op cognitief-gedragsmatige interventies die bedoelden gevoelens van competentie te vergroten, copinggedrag aan te leren en sociale steun te vergroten, of op ontspanningsoefeningen. Organisatiegerichte interventies richtten zich vaak op de manier waarop het werk was georganiseerd, de manier van leidinggeven, het vergroten van regelmogelijkheden en het verlagen van taakeisen. Uit hun overzichtsstudie bleek dat $80 \%$ van deze interventies op kortere termijn (zes maanden of minder) inderdaad tot een afname van burnout leidde. Deze effecten beklijfden langer (twaalf maanden of meer) als de interventie zowel persoons- als organisatiegerichte maatregelen bevatte, maar in alle gevallen verminderden de positieve effecten van de interventie over de tijd. Hoewel sinds de overzichtsstudie van Awa en collega's nog diverse andere interventiestudies zijn gepubliceerd (bijvoorbeeld Lloyd et al., 2013; Salmela-Aro et al., 2011), zijn de resultaten daarvan vergelijkbaar met die van Awa et al. (2010). Al met al kan geconcludeerd worden dat zowel persoons- als organisatiegerichte interventies effectief kunnen zijn in het terugdringen van burnout, maar ook dat continue aandacht voor het beheersen van burnout noodzakelijk is om deze positieve effecten vast te houden.

\section{Burnout: wat nu?}

In deze bijdrage wilden we de lezer een overzicht geven van de stand van zaken in het onderzoek naar burnout. We hebben aangegeven wat burnout is, hoe het kan worden vastgesteld, waar de belangrijkste oorzaken voor burnout te vinden zou- 
den zijn, en wat de gevolgen van burnout zijn voor het functioneren en de gezondheid van werknemers, en hebben laten zien dat interventies ingezet kunnen worden om burnout te verminderen. Al met al kan geconcludeerd worden dat de afgelopen veertig jaar veel waardevolle en interessante inzichten hebben opgeleverd met betrekking tot het ontstaan, de gevolgen en de aanpak van burnout.

Dat betekent echter niet dat de discussie over burnout gesloten is. Eén belangrijk aandachtspunt betreft bijvoorbeeld de conceptualisatie van burnout. Eerder hebben we burnout in de lijn van Maslach en Jackson $(1981,1986)$ gedefinieerd als een werkgerelateerd syndroom van uitputting, distantie en verminderde competentie. Factor-analytisch onderzoek (bijvoorbeeld Schaufeli et al., 2009) heeft echter laten zien dat van deze drie componenten uitputting en distantie de centrale componenten zijn, en dat verminderde competentie relatief zwak samenhangt met de andere twee componenten. Andere onderzoekers hebben laten zien dat hoge niveaus van burnout serieuze consequenties hebben voor het cognitieve functioneren (bijvoorbeeld het concentratievermogen en het vermogen om informatie te verwerken) van werknemers (onder meer Oosterholt et al., 2012; Van Dam, 2013). Dit suggereert dat het tijd is om de klassieke driedimensionale conceptualisatie van burnout te vervangen door een opvatting waarbij (werkgerelateerde) uitputting en distantie gepaard gaan met verminderd cognitief functioneren, waarbij affect (uitputting), motivatie (distantie) en prestatie (cognitief functioneren) elkaar over en weer kunnen beïnvloeden (Van Dam, 2013). Voor twijfel aan het eigen functioneren (verminderde competentie) zou in zo'n opvatting geen plaats meer zijn.

Een tweede aandachtspunt voor onderzoek naar burnout betreft de ontwikkeling van burnout over de tijd, in relatie tot betrokkenheid bij het werk. Eerder in dit artikel zagen we al dat overbetrokkenheid een risicofactor was voor burnout (Siegrist, 2002; Van Vegchel et al., 2005). Een hoge betrokkenheid is echter ook een van de kerncomponenten van bevlogenheid, in veel opzichten de tegenpool van burnout. Dat doet de vraag rijzen of bevlogenheid (als vorm van hoge betrokkenheid) wellicht een risicofactor is voor het ontstaan van burnout. Uit kwalitatieve interviews met opgebrande werknemers kwamen enige aanwijzingen dat juist dit type werknemers aanvankelijk zeer bevlogen was (Schaufeli et al., 2001). $\mathrm{Al}$ wat ouder onderzoek naar het type A gedragspatroon (dat zich kenmerkt door een grote behoefte aan controle en grote betrokkenheid) liet zien dat type A personen met name als het tegenzat met de carrière een extreme mate van vermoeidheid rapporteren - wat ook kenmerkend is voor burnout (zie Matsinger et al., 1986). Ook weten we dat werkverslaafde werknemers (die vaak zeer betrokken zijn bij hun werk) relatief hoge scores rapporteren op burnout (Taris et al., 2005). Al met al lijkt de relatie tussen (overmatig) hoge werkbetrokkenheid, bevlogenheid en burnout een interessant onderwerp voor verder onderzoek.

Een derde interessante lijn van onderzoek betreft de identificatie van risicoberoepen voor burnout. Als de belangrijkste risicofactoren voor burnout gelegen zijn in aspecten van de werksituatie (zoals het moeten omgaan met hoge emotionele, kwantitatieve dan wel kwalitatieve taakeisen), ligt het voor de hand om te veronderstellen dat specifieke beroepen een hoger risico op burnout opleveren dan andere beroepen. Studies waarin beroepsgroepen of specifieke beroepen met 
elkaar worden vergeleken in termen van burnoutrisico zijn echter schaars. Eén studie waarin 28 contactuele beroepen met elkaar worden vergeleken in termen van burnoutrisico is gebaseerd op de normgegevens van de Nederlandse versie van de MBI (Bakker et al., 2000). Relatief hoge niveaus van burnout werden gevonden bij verpleegkundigen, psychiaters, verloskundigen, arbo-artsen en huisartsen, terwijl relatief lage niveaus gevonden werden voor politiemedewerkers en radiologisch laboranten. Zestien procent van de verschillen in burnoutrisico tussen deze beroepen werd verklaard door verschillen in regelmogelijkheden (Taris et al., 2005). Deze resultaten laten zien dat beroepen van elkaar kunnen verschillen in termen van burnoutrisico, maar er is zeker behoefte aan onderzoek waarin een veel breder scala aan beroepen wordt vergeleken - bijvoorbeeld in het licht van de recente discussie over de verhoging van de pensioenleeftijd voor zware versus andere beroepen.

Een vierde aandachtspunt voor verder onderzoek naar burnout betreft de langetermijneffecten van burnout, zijn objectiveerbare effecten (op bijvoorbeeld cognitie en prestatie), en de manier waarop de inzetbaarheid en participatie van opgebrande werknemers weer op peil kunnen worden gebracht. Veel van het in deze bijdrage besproken onderzoek is gebaseerd op zelfrapportages en cross-sectionele designs, waarin het per definitie onmogelijk is harde conclusies te trekken over oorzaak en gevolg. We weten daarom op dit moment nog weinig van de ontwikkeling, het beloop en het herstel van burnout op langere termijn, terwijl dergelijke kennis wel noodzakelijk is om burnout effectief te kunnen voorkomen dan wel om de gevolgen daarvan te kunnen inschatten.

Ten slotte, een meer praktisch punt voor verder onderzoek betreft de validatie van de UBOS, het meest gebruikte instrument om burnout vast te stellen. Hoewel de afkappunten van dit instrument klinisch zijn gevalideerd (Schaufeli \& Van Dierendonck, 2000), zijn deze gebaseerd op onderzoek dat zo'n vijftien tot twintig jaar geleden werd uitgevoerd. De Commissie Testaangelegenheden van het Nederlands Instituut van Psychologen (COTAN) stelt hieromtrent dat 'normen zijn aan slijtage onderhevig (...) daarom moet er van tijd tot tijd hernormering plaatsvinden' (COTAN, 2010, pp. 21). De commissie acht normen die meer dan vijftien jaar geleden zijn vastgesteld 'verouderd', en normen die meer dan twintig jaar geleden zijn vastgesteld 'niet meer bruikbaar'. Dit betekent dat de UBOS inmiddels toe is aan hernormering. 


\section{Literatuur}

Adams, J.S. (1965). Inequity in social exchange. In L. Berkowitz (red.), Advances in Experimental Social Psychology (vol. 2, pp. 267-299). New York: Academic Press.

Ahola, K., Kivimaki, M., Honkonen, T., Virtanen, M., Koskinen, S., Vahtera, J. \& Lonnquist, J. (2008). Occupational burnout and medically certified sickness absence: A population-based study of Finnish employees. Journal of Psychosomatic Research, 64, 185-193.

Ahola, K., Toppinen-Tanner, S., Huuhtanen, P., Koskinen, A. \& Vaananen, A. (2009). Occupational burnout and chronic work disability: An eight-year cohort study on pensioning among Finnish forest industry workers. Journal of Affective Disorders, 115, 150-159.

Alarcon, G., Eschleman, K.J. \& Bowling, N.A. (2009). Relationships between personality variables and burnout: A meta-analysis. Work \& Stress, 23, 244-263.

Awa, W.L., Plaumann, M. \& Walter, U. (2010). Burnout prevention: A review of intervention programs. Patient Education and Counseling, 78, 184-190.

Bakker, A.B., Demerouti, E. \& Verbeke, W. (2004). Using the Job Demands-Resources model to predict burnout and performance. Human Resource Management, 43, 83-104.

Bakker, A.B. \& Heuven, E. (2006). Emotional dissonance, burnout, and in-role performance among nurses and police officers. International Journal of Stress Management, $13,423-440$.

Bakker, A., Schaufeli, W. \& Dierendonck, D. van (2000). Burnout: Prevalentie, risicogroepen en risicofactoren. In I.L.D. Houtman, W.B. Schaufeli \& T. Taris (red.), Psychische vermoeidheid en werk (pp. 65-82). Alphen a/d Rijn: Samsom.

Centraal Bureau voor de Statistiek (2013). Burn-outklachten. Gedownload op 9 april 2013 van www.cbs.nl/nl-NL/menu/methoden/toelichtingen/alfabet/b/burn-outklachten. htm.

COTAN (2010). COTAN beoordelingssysteem voor de kwaliteit van tests (gewijzigde herdruk). Amsterdam: Nederlands Instituut van Psychologen.

Craig, C.D. \& Sprang, G. (2010). Compassion satisfaction, compassion fatigue, and burnout in a national sample of trauma treatment therapists. Anxiety, Stress, and Coping, 23, 319-339.

Crawford, E.R., LePine, J.A. \& Rich, B.L. (2010). Linking job demands and resources to employee engagement and burnout: A theoretical extension and meta-analytic test. Journal of Applied Psychology, 95, 834-848.

Dam, A. van (2013). Studies on cognitive performance in burnout (academisch proefschrift). Nijmegen: Radboud Universiteit Nijmegen.

Danhof-Pont, M.B., Veen, T. van \& Zitman, F.G. (2011). Biomarkers in burnout: A systematic review. Journal of Psychosomatic Research, 70, 505-524.

Demerouti, E. \& Bakker, A.B. (2007). The Oldenburg Burnout Inventory: A good alternative to measure burnout (and engagement). In J.R.B. Halbesleben (red.), Handbook of work stress in health care (pp. 65-78). Hauppauge, NY: Nova.

Demerouti, E., Bakker, A.B., Nachreiner, F. \& Schaufeli, W.B. (2001). The job demandsresources model of burnout. Journal of Applied Psychology, 86, 499-512.

Dierendonck, D. van, Schaufeli, W.B. \& Buunk, B.P. (1996). Equity among human services professionals: Measurement and relation to burnout. Basic and Applied Psychology, 18, 429-451.

Doef, M. van der \& Maes, S. (1999). The job demand-control-support model and psychological well-being: A review of 20 years of empirical research. Work \& Stress, 13, 87-114. 
Geurts, S.A.E., Beckers, D.G.J. \& Tucker, P. (in druk). Recovery from demanding work hours. In M.C.W. Peeters, J. de Jonge \& T.W. Taris (red.), An introduction to contemporary work psychology. Chichester, VK: Wiley.

Hakanen, J.J. \& Schaufeli, W.B. (2012). Do burnout and work engagement predict depressive symptoms and life satisfaction? A three-wave seven-year prospective study. Journal of Affective Disorders, 141, 415-424.

Halbesleben, J.R.B. (2010). A meta-analysis of work engagement: Relationships with burnout, demands, resources, and consequences. In A.B. Bakker \& M.P. Leiter (red.), Work engagement: A handbook of essential theory and research (pp. 102-117). New York: Psychology Press.

Hall, G.B., Dollard, M.F., Tuckey, M.R., Winefield, A.H. \& Thompson, B.M. (2010). Job demands, work-family conflict, and emotional exhaustion in police officers: A longitudinal test of competing theories. Journal of Occupational and Organizational Psychology, 83, 237-250.

Hallsten, L., Voss, M., Stark, S., Josephson, M. \& Vingard, E. (2011). Job burnout and job workout as risk factors for long-term sickness absence. Work: Journal of Prevention, Assessment \& Rehabilitation, 38, 181-192.

Hausser, J.A., Mojzisch, A., Niesel, M. \& Schulz-Hardt, S. (2010). Ten years on: A review of recent research on the job demand-control(-support) model and psychological wellbeing. Work \& Stress, 24, 1-35.

Heiden, C. van der \& Hoogduin, C.A.L. (2002). Burn-out: Diagnostiek en behandeling. Tijdschrift voor Bedrijfs- en Verzekeringsgeneeskunde, 10, 43-48.

Jonge, D. de, Demerouti, E. \& Dormann, C. (in druk). Modern theoretical perspectives in work psychology. In M.C.W. Peeters, J. de Jonge \& T.W. Taris (red.), An introduction to contemporary work psychology. Chichester, VK: Wiley.

Jonge, J. de \& Dormann, C. (2006). Stressors, resources, and strain at work: A longitudinal test of the Triple-Match Principle. Journal of Applied Psychology, 91, 1359-1374.

Karasek, R.A. (1979). Job demands, job decision latitude, and mental strain: Implications for job design. Administrative Science Quarterly, 24, 285-308.

Koppes, L.L.J., Vroome, E.M.M. de, Mars, G.M.J., Janssen, B.J.M., Zwieten, M.H.J. van \& Bossche, S.N.J. van den (2013). Nationale Enquête Arbeidsomstandigheden 2012: Methodologie en globale resultaten. Hoofddorp: TNO.

Kristensen, T.S., Borritz, M., Villadsen, E. \& Christensen, K.B. (2005). The Copenhagen Burnout Inventory: A new tool for the assessment of burnout. Work \& Stress, 19, 192-207.

Lange, A.H. de, Taris, T.W., Kompier, M.A., Houtman, I.L.D. \& Bongers, P.M. (2003). 'The very best of the millennium': Longitudinal research and the demands-control (support) model. Journal of Occupational Health Psychology, 8, 282-305.

Lau, B. (2008). Effort-reward imbalance and overcommitment in employees in a Norwegian municipality: A cross-sectional study. Journal of Occupational Medicine and Toxicology, 3, 9.

Lloyd, J., Bond, F.W. \& Flaxman, P.E. (2013). The value of psychological flexibility: Examining psychological mechanisms underpinning a cognitive behavioural therapy intervention for burnout. Work \& Stress, 27, 181-199.

Luchman, J.N. \& Gonzàlez-Morales, M.G. (2013). Demands, control and support: A metaanalytic review of work characteristics interrelationships. Journal of Occupational Health Psychology, 18, 37-52.

Maslach, C. \& Jackson, S.E. (1981). The measurement of experienced burnout, Journal of Occupational Behavior, 2, 99-113. 
Maslach, C. \& Jackson, S.E. (1986). Maslach Burnout Inventory (2de druk) (testhandleiding). Palo Alto, CA: Consulting Psychologists Press.

Maslach, C., Leiter, M.P. \& Schaufeli, W.B. (2008). Measuring burnout. In C.L. Cooper \& S. Cartwright (red.), The Oxford handbook of organizational well-being (pp. 86-108). Oxford: Oxford University Press.

Maslach, C. \& Schaufeli, W.B. (1993). Historical and conceptual development of burnout. In W.B. Schaufeli, C. Maslach \& T. Marek (red.), Professional burnout: Recent developments in theory and research (pp. 1-16). New York: Taylor \& Francis.

Matsinger, H., Siegrist, J., Siegrist, K. \& Dittman, K.H. (1986). Type A as a coping career: Toward a conceptual and methodological redefinition. In T.H. Schmidt, T.M. Dembroski \& G. Blümchen (red.), Biological and psychological factors in cardiovascular disease: Part I (pp. 104-126). Berlijn: Springer-Verlag.

Meijman, T.F. \& Mulder, G. (1998). Psychological aspects of workload. In P.J. Drenth, H. Thierry \& C.J. de Wolff (red.), Handbook of work and organizational psychology (2de druk) (pp. 5-33). Hove, VK: Psychology Press.

Oosterholt, B.G., Linden, D. van der, Maes, J.H.R., Verbraak, M.J.P.M. \& Kompier, M.A.J. (2012). Burned out cognition: A study of cognitive functioning before and after a period with psychological treatment. Scandinavian Journal of Work Environment \& Health, 38, 258-269.

Salmela-Aro, K., Naatanen, P., Tolvanen, A. \& Nurmi, J.E. (2011). Changes in goal-related affects: Decrease burnout during a group psychotherapy intervention. European Journal of Work and Organizational Psychology, 20, 451-466.

Schaufeli, W.B. (2006). The balance of give and take: Toward a social exchange model of burnout. Revue Internationale de Psychologie Sociale, 19, 87-131.

Schaufeli, W.B. (2012). The measurement of work engagement. In R.R. Sinclair, M. Wang \& L.E. Tetrick (red.), Research methods in occupational health psychology: Measurement, design, and data analysis (pp. 138-153). New York: Routledge.

Schaufeli, W.B. \& Bakker, A.B. (2004). Bevlogenheid: Een begrip gemeten. Gedrag \& Organisatie, 17, 89-112.

Schaufeli, W. \& Bakker, A. (2013). Burnout en bevlogenheid. In W. Schaufeli \& A. Bakker (red.), De psychologie van arbeid en gezondheid (3e druk) (pp. 305-322). Houten: Bohn Stafleu Van Loghum.

Schaufeli, W.B., Bakker, A.B. \& Rhenen, W. van (2009). How changes in job demands and resources predict burnout, work engagement, and sickness absenteeism. Journal of Organizational Behavior, 30, 893-917.

Schaufeli, W.B. \& Dierendonck, D. van (2000). Utrechtse Burnout Schaal (UBOS). Lisse: Swets \& Zeitlinger.

Schaufeli, W.B., Leiter, M.P., Maslach, C. \& Jackson, S.E. (1996). Maslach Burnout Inventory - General Survey. In C. Maslach, S.E. Jackson \& M.P. Leiter, The Maslach Burnout Inventory (3de druk) (testhandleiding). Palo Alto: Consulting Psychologists Press.

Schaufeli, W.B., Leiter, M.P. \& Maslach, C. (2009). Burnout: 35 years of research and practice. Career Development International, 14, 204-220.

Schaufeli, W.B. \& Taris, T.W. (2005). The conceptualization of burnout: Common ground and worlds apart. Work \& Stress, 19, 256-262.

Schaufeli, W.B. \& Taris, T.W. (2013). Het job demands-resources model: Overzicht en kritische beschouwing. Gedrag \& Organisatie, 26, 182-204.

Schaufeli, W., Taris, T., Blanc, P. le, Peeters, M., Bakker, A. \& Jonge, J. de (2001). Maakt arbeid gezond? Op zoek naar de bevlogen werknemer. De Psycholoog, 36, 422-428. 
Schaufeli, W.B., Taris, T.W. \& Rhenen, W. van (2008). Workaholism, burnout, and work engagement: Three of a kind or three different kinds of employee well-being? Applied Psychology: An International Review, 57, 173-203.

Schmidt, A.J.M. (2001). Overspannen, depressief, burnout, of chronisch vermoeid: Een diagnostische grabbelton? Huisarts \& Wetenschap, 44, 283-287.

Shirom, A. \& Melamed, S. (2005). Does burnout affect physical health? A review of the evidence. In A.S. Antoniou \& C.L. Cooper (red.), Research companion to organizational health psychology (pp. 599-622). Northampton, MA: Edward Elgar.

Siegrist, J. (2002). Effort-Reward imbalance at work and health. In P.L. Perrewé \& D.C. Ganster (red.), Historical and current perspectives on stress and health (pp. 261-291). Washington: JAI Press.

Swider, B.W. \& Zimmermann, R.D. (2010). Born to burnout: A meta-analytic path model of personality, job burnout, and work outcomes. Journal of Vocational Behavior, 76, 487-506.

Taris, T.W. (2006a). Bricks without clay: On urban myths in occupational health psychology. Work \& Stress, 20, 99-104.

Taris, T.W. (2006b). Is there a relationship between burnout and objective performance? A critical review of 16 studies. Work \& Stress, 20, 316-334.

Taris, T.W., Bakker, A.B., Schaufeli, W.B., Stoffelsen, J. \& Dierendonck, D. van (2005). Job control and burnout across occupations. Psychological Reports, 97, 955-961.

Taris, T.W., Beckers, D.G.J., Verhoeven, L.C., Geurts, S.A.E., Kompier, M.A.J. \& Linden, D. van der (2006). Recovery opportunities, work-home interference, and well-being among managers. European Journal of Work and Organizational Psychology, 15, 139-157.

Taris, T.W., Schaufeli, W.B. \& Verhoeven, L.C. (2005). Workaholism in the Netherlands: Measurement and implications for job strain and work-nonwork conflict. Applied Psychologie: An International Review, 54, 37-60.

Terluin, B. (1998). De Vierdimensionale klachtenlijst (4DKL) in de huisartspraktijk. De Psycholoog, 33, 18-24.

Teuchmann, K., Totterdell, P. \& Parker, S.K. (1999). Rushed, unhappy, and drained: An experience sampling study of relations between time pressure, perceived control, mood, and emotional exhaustion in a group of accountants. Journal of Occupational Health Psychology, 4, 37-54.

Vegchel, N. van, Jonge, J. de, Bosma, H. \& Schaufeli, W.B. (2005). Reviewing the EffortReward Imbalance model: Drawing up the balance of 45 empirical studies. Social Science and Medicine, 60, 1117-1131.

Verbraak, M., Kleyweg, J., Griendt, J. van de \& Hoogduin, K. (2008). Nadere verkenning van de psychometrische kwaliteiten van de BurnOut-Neurasthenie Klachten Schaal (BO-NKS): wat valt er te meten? Directieve Therapie, 28, 187-2. 